\title{
III Consenso Brasileiro para Pesquisa de Autoanticorpos em Células HEp-2: perspectiva histórica, controle de qualidade e associações clínicas
}

\author{
Third Brazilian Consensus for Autoantibodies Screening in HEp-2 Cells: historical perspective, quality control and clinical \\ associations
}

Paulo Luiz Carvalho Francescantonio', Luis Eduardo Coelho Andrade², Wilson de Melo Cruvinel ${ }^{3}$, Flávia Ikeda e Araújo ${ }^{4}$, Alessandra Dellavance ${ }^{5}$, Alexandre Gabriel Júnior ${ }^{6 \#}$, Barbara Nuccitelli ${ }^{7}$, Ben Hur Taliberti ${ }^{8}$, Carlos Alberto von Mühlen ${ }^{9}$, Carlos David Araújo Bichara $^{10}$, Cláudio Henrique Ramos dos Santos ${ }^{11}$, Cleonice Bueno ${ }^{12}$, Cristiane Martinez Yano ${ }^{13}$, Cristóvão Luis Pitangueira Mangueira ${ }^{14}$, Darlene Gonçalves Carvalho ${ }^{15}$, Elizângela Cardoso ${ }^{16}$, Eloísa Bonfá17, Gustavo Gabriel Rassi ${ }^{18}$, Hugo Mendonça Mundim ${ }^{19}$, Izidro Bendet $^{20}$, Jozélia Rego ${ }^{21}$, Lisiane Maria Enriconi dos Anjos Vieira ${ }^{22}$, Maria Ordália Ferro Barbosa ${ }^{23}$, Mitiko Sugiyama ${ }^{24}$, Mittermayer Barreto Santiago ${ }^{25}$, Natasha Slhessarenko ${ }^{26}$, Nilzio Antônio da Silva ${ }^{27}$, Renata Jarach ${ }^{28}$, Roberto Suda ${ }^{29}$, Roger Abramino Levy ${ }^{30}$, Silvia Oliveira Sampaio ${ }^{31}$, Suzane Pretti Figueiredo Neves $^{32}$, Wilton Silva dos Santos ${ }^{33}$, Yanna K. de M. Nóbrega ${ }^{34}$

unitermos
Autoanticorpos
Células HEp-2
Anticorpos antinúcleo
Imunofluorescência
indireta

\section{resumo}

Objetivo: O III Consenso Brasileiro para Pesquisa de Autoanticorpos em Células HEp-2 (FAN) objetivou discutir estratégias para controlar a qualidade do ensaio, promover a atualização das associações clínicas dos diversos padrões e avaliar as dificuldades de implantação do II Consenso ocorrido no ano de 2002. Métodos: Nos dias 13 e 14 de abril de 2007 participaram do encontro em Goiânia pesquisadores e especialistas de diversos centros universitários e laboratórios clínicos de diferentes regiões do Brasil, com o propósito de discutir e aprovar as recomendações que visam a melhores padronização, interpretação e utilização do ensaio pelos clínicos. Foram convidados como ouvintes representantes comerciais de diferentes empresas produtoras de insumos para realização do teste de FAN. Resultados e conclusão: Dada a heterogeneidade de microscópios e reagentes disponíveis no mercado, o III Consenso enfatizou a necessidade do controle de qualidade em ensaios de imunofluorescência indireta. Foram também feitas algumas adequações na terminologia utilizada para classificar os diferentes padrões. Finalmente, foi realizada uma atualização das associações clínicas com finalidade de facilitar cada vez mais o melhor uso do ensaio pelos clínicos.

\section{abstract}

Objective: The Third Brazilian Consensus for Autoantibodies Screening in HEp-2 Cells (ANA) had as purpose the evaluation of difficulties in the accomplishment of the 2nd Consensus recommendations that took place in the year of 2002, the discussion of strategies for quality control of the assay and the discussion of an update of the clinical associations of the several immunofluorescent patterns. Methods: Several ANA experts from university centers and private laboratories in different areas in Brazil joined the workshop in Goiânia on 2007 April 13 and 14 with the purpose of discussing and approving the recommendations for standardization, interpretation and use of the test by physicians. Commercial representatives of different ANA slide brands were also invited as listeners to the workshop. Results and conclusion: The 3rd ANA Consensus emphasized the need for quality control in indirect immunofluorescent assays since there is a considerable heterogeneity of available microscopes and reagents. It also promoted adaptations in the previously approved terminology used to classify the different patterns and finally updated the clinical associations of the several patterns with the purpose of providing guidance for interpretation of the assay by clinical pathologists and assistant physicians.

\section{key words}

Autoantibodies

HEp-2 cells

Antinuclear antibodies

Indirect

immunofluorescence

assays

\footnotetext{
\# in memoriam

1. Mestre em Ciências Ambientais e Saúde pela Universidade Católica de Coiás (UCG); professor assistente I de Imunologia dos cursos de Biomedicina e Medicina da UCC; coordenador do III Consenso Brasileiro para Pesquisa de Autoanticorpos.

2. Professor associado; livre docente da disciplina de Reumatologia na Universidade Federal de São Paulo (UNIFESP); coordenador do Programa de Pós-Craduação da disciplina de Reumatologia da UNIFESP; assessor-médico do setor de Imunologia do Fleury Medicina e Saúde.

3. Doutorando de Reumatologia pela UNIFESP; professor assistente de Imunologia nos cursos de Biomedicina e Medicina da UCC; secretário do III Consenso Brasileiro para Pesquisa de Autoanticorpos.

4. Mestra em Ciências Ambientais e Saúde pela UCC; professora assistente I de Imunologia do curso de Biomedicina da UCC; coordenadora do Laboratório de Apoio Didático do Departamento de Biomedicina da UCC.

5. Doutoranda de Reumatologia pela UNIFESP; assessora científica do setor de Imunologia do Fleury Medicina Diagnóstica.

6. Pós-doutorado pela Scripps Medical Center La Jolla La USA; coordenador médico da AFIP-Medicina Laboratorial e Centro Imuno-Reumatológico de São Paulo.

7. Biomédica do Padrão Laboratório Clínico.

8. Pós-doutor pela Reumaklinik Aachen, Alemanha; professor titular de clínica médica da Universidade Federal de Uberlândia (UFU); coordenador do serviço de reumatologia do Hospital das Clínicas da UFU.
} 


\section{Introdução}

\section{A pesquisa de autoanticorpos em células HEp-2 no Brasil}

A medicina laboratorial tem vivenciado uma constante evolução científico-tecnológica que repercute nos exames laboratoriais, afetando parâmetros importantes para a interpretação clínica, como os valores preditivos positivo e negativo, a sensibilidade e a especificidade. Essa realidade pode ser ilustrada em procedimentos laboratoriais, como na pesquisa de anticorpos antinúcleo (ANA), pela técnica de imunofluorescência indireta (IFI) em células HEp-2, também conhecido como fator antinúcleo (FAN), hoje denominado "pesquisa de anticorpos contra antígenos celulares" (PAAC). Trata-se de um excelente exame de rastreamento de autoanticorpos em soro de pacientes com suspeita de doença autoimune que, ao longo das últimas décadas, foi tecnicamente modificado, de forma a conferir sensibilidade progressivamente maior. Como consequência, a pesquisa de anticorpos contra antígenos celulares passou também a apresentar menor especificidade ${ }^{(17)}$.

No entanto, a maior sensibilidade do teste de PAAC-IFI em HEp-2 trouxe algum prejuízo na especificidade, pois resultados reagentes são observados em amostras de alguns indivíduos sem evidência clínica ou laboratorial aparente de doença autoimune. Este cenário exige interpretação criteriosa dos achados sorológicos ${ }^{(19)}$. A alta frequência de resultados positivos do teste em indivíduos saudáveis ou com manifestações clínicas vagas tem trazido à tona uma situação denominada por alguns de "síndrome do anticorpo antinúcleo idiopático" (17). A perda de especificidade do teste agravou-se também pelo fato de que uma vasta gama de especialistas médicos passou a utilizá-lo. Inicialmente, os reumatologistas e nefrologistas eram os grandes usuários desse exame e, em decorrência de sua familiaridade com o mesmo e das características de sua clientela, tinham maior chance de solicitar o exame a quem realmente tivesse quadro autoimune. Gradativamente o teste vem sendo solicitado por especialistas em outras áreas, como gastroenterologia, ginecologia, ortopedia, otorrinolaringologia, neurologia, psiquiatria, entre outras. Isto reforça a necessidade de fundamentarmos que o ensaio deve ser considerado como um teste de triagem e a interpretação e a valorização do resultado devem estar fundamentadas no conhecimento da sensibilidade e especificidade do mesmo e no contexto clínico particular ${ }^{(15,13)}$. Atualmente, o PAAC-IFI em HEp-2 é um exame solicitado com menos critério por grande variedade de especialistas, que obviamente atendem pacientes distintos, nos quais o diagnóstico de doença reumática autoimune é menos prevalente. Portanto, a chance de resultados reagentes em indivíduos saudáveis ou com apresentações clínicas pouco expressivas tornou-se maior. Alguns elementos são importantes para a valorização adequada do teste do PAAC-IFI em HEp-2. Em primeiro lugar, o exame deve ser solicitado apenas quando houver suspeita convincente de doença autoimune. Sua solicitação frente a um paciente com queixas vagas frequentemente trará mais confusão ao raciocínio clínico, visto que um resultado positivo não implica necessariamente em autoimunidade.

Um segundo ponto a ser considerado é o título do PAACIFI em HEp-2: em geral, os pacientes autoimunes tendem a apresentar títulos moderados (1/160 e 1/320) e elevados $(\geq 1 / 640)$, enquanto os indivíduos sadios com PAAC-IFI em HEp-2 positivo tendem a apresentar baixos títulos $(1 / 80)^{(37)}$. Entretanto, em ambas as situações pode haver exceções ${ }^{(29)}$. Outro ponto importante é o padrão de fluorescência, que fornece uma indicação da identidade do(s) autoanticorpo(s) em questão ${ }^{(21)}$ e deve ser analisado com bastante cautela. Para sua caracterização será levada em consideração a experiência e expertise do observador, a capacidade de se reproduzir o padrão por parte do kit, que pode ser de diferentes fabricantes, e os parâmetros técnicos relacionados com o controle de qualidade da imunofluorescência indireta ${ }^{(13)}$.

Autoanticorpos contra alguns antígenos têm associação bastante específica com determinadas doenças autoimunes ou ao estado de autoimunidade em si, enquanto outros ocorrem indiscriminadamente em indivíduos autoimunes e não-autoimunes. Dessa forma, determinados padrões de fluorescência são mais específicos de doença autoimune, enquanto outros ocorrem com frequência em indivíduos sadios ou em pacientes com outras enfermidades nãoautoimunes ${ }^{(17)}$.

Outro ponto a se considerar é que o nível de autoimunidade fisiológica, ou basal, pode flutuar na dependência de sobrecargas a que o sistema imunológico seja exposto. Está bem demonstrada a presença de autoanticorpos desencadeada transitoriamente por infecções, por medicamentos e por neoplasias. Tem sido demonstrada claramente alta prevalência de autoanticorpos em pacientes infectados pelo vírus da imunodeficiência humana (HIV) e por outros vírus linfotrópicos ${ }^{(31)}$. Portanto, outra consideração a ser feita ante um paciente com um achado positivo de PAAC-IFI em HEp-2 refere-se a possibilidade de infecções virais recentes, uso de medicamentos e processos neoplásicos. 
Várias evidências demonstram que os autoanticorpos frequentemente precedem à eclosão clínica das doenças autoimunes ${ }^{(6)}$. Um teste de PAAC-IFI em HEp-2 positivo pode preceder o aparecimento clínico do LES em até nove anos. Cerca de $80 \%$ dos pacientes com LES apresentam PAAC-IFI em HEp-2 positivo antes do aparecimento dos primeiros sintomas. O mesmo é válido, embora em menor porcentagem, para os vários autoanticorpos específicos dessa enfermidade, como anti-DNA nativo e anti-Sm. Portanto, outra possibilidade a se considerar em presença de um achado clinicamente inconsistente de PAAC-IFI em HEp-2 positivo é a de que o paciente poderá vir a desenvolver uma doença autoimune nos próximos anos. No entanto, alguns indivíduos podem seguir décadas com autoanticorpos circulantes sem desenvolver qualquer sinal de enfermidade autoimune ${ }^{(12)}$.

Perante um resultado positivo de PAAC-IFI em HEp-2 é imprescindível que se caracterize essa reatividade, buscando a presença de anticorpos peculiares de patologias autoimunes por meio de técnicas específicas. Essa investigação deve ser subsidiada pela busca de evidência clínica ou laboratorial de doença autoimune sistêmica. Além do exame clínico apurado, é importante verificar possíveis alterações em hemograma, urina I, proteína C-reativa (PCR) e velocidade de hemossedimentação (VHS), que podem ser consideradas extensões do exame clínico. Na dependência da apresentação clínica, pode ser válido investigar enzimas hepáticas e musculares. A presença de sintomas vagos, como artralgia e astenia, com exames laboratoriais gerais normais, não é suficiente para subsidiar um achado laboratorial de PAAC-IFI em HEp-2 em título baixo e com padrão de fluorescência pouco específico. Nesses casos, deve-se exercitar o bom senso e proceder ao acompanhamento clínico do paciente em consultas regulares.

Levando-se em consideração essa problemática, os dois primeiros consensos contribuíram para o aperfeiçoamento das leituras e a interpretação dos padrões de PAAC-IFI em HEp-2 a partir da criação de critérios morfológicos a serem seguidos durante a leitura do teste. No I Consenso foram instituídas as árvores de classificação para os diversos padrões, a partir da combinação dos critérios, formando os grupos principais (núcleo, nucléolo, citoplasma e aparelho mitótico). De fato, a grande diversidade e heterogeneidade de terminologia então utilizada para caracterizar os diferentes padrões foi o ensejo para a realização do consenso(14).

No II Consenso foram ratificados os algoritmos de decisão para leitura dos padrões na imunofluorescência indireta vistos na primeira edição do consenso brasileiro, adicionando-se ainda o algoritmo para os padrões mistos. Tendo em vista a habilidade do teste em detectar autoantígenos nos distintos compartimentos celulares, e não apenas no núcleo, foram propostas algumas denominações para este exame laboratorial que expressasse a totalidade de sua dimensão diagnóstica:

- FAN - pesquisa de anticorpos contra componentes do núcleo, nucléolo, citoplasma e aparelho mitótico;

- FAN - Pesquisa de autoanticorpos;

- pesquisa de autoanticorpos (FAN e citoplasmáticos);

- pesquisa de anticorpos contra componentes do núcleo (FAN), nucléolo, citoplasma e aparelho mitótico;

- pesquisa de autoanticorpos - núcleo (FAN), nucléolo, citoplasma e aparelho mitótico;

- pesquisa de autoanticorpos contra antígenos intracelulares (FAN HEp-2).

O II Consenso recomendou ainda a elaboração de laudos descritivos com o propósito de aprimorar a leitura da lâmina pelos profissionais de laboratório. O laudo deve contemplar os padrões de fluorescência observados em núcleo, nucléolo, citoplasma, aparelho mitótico e na placa metafásica cromossômica, bem como o título dos respectivos padrões. $\mathrm{Na}$ Figura 1 estão representados dois exemplos de laudos, conforme as recomendações do consenso.

Ainda por ocasião do II Consenso foram abordadas informações sobre as principais associações clínicas dos diferentes padrões. Na Tabela estão resumidas as justificativas que fundamentaram a realização dos consensos e

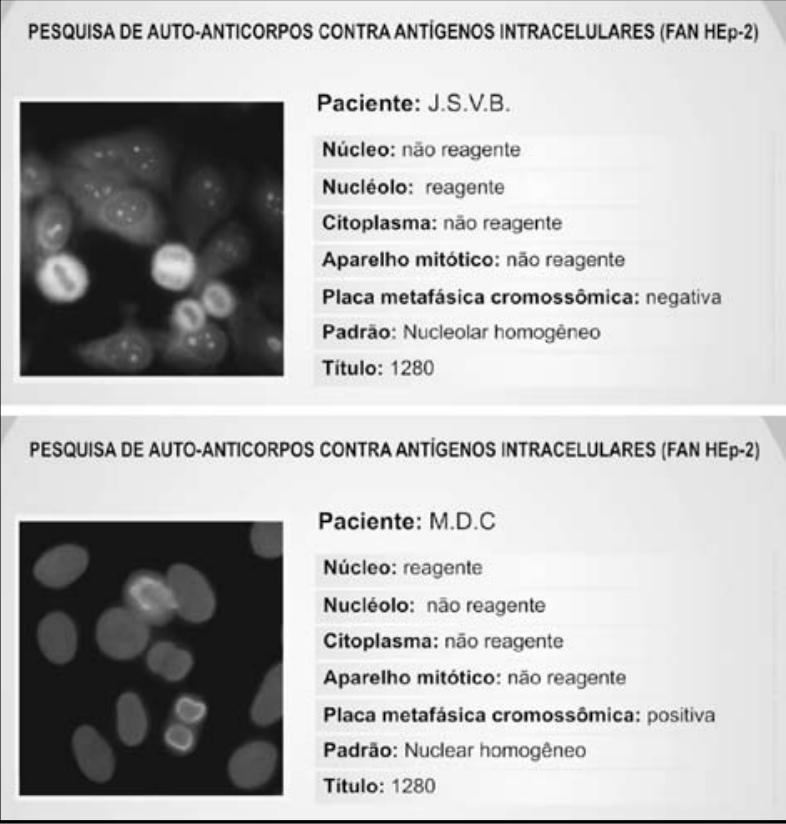

Figura 1 - Exemplos de laudos descritivos conforme as recomendações dos consensos 
as recomendações deliberadas pelos participantes. Como pode ser observado, após a implantação do l e ll Consensos, surgiram dificuldades que motivaram a realização de um novo encontro. Na ocasião da implantação do II Consenso, um dos problemas observados refere-se à classificação do padrão nuclear homogêneo quanto à reatividade dos nucléolos e com relação à classificação dos padrões mistos englobando múltiplas reatividades dentro do mesmo grupo, por exemplo, um padrão com dois ou mais autoanticorpos contra antígenos nucleares. Outro aspecto relevante, detectado após o II Consenso, foi a necessidade de alertar quanto à heterogeneidade dos reagentes e substratos, como, por exemplo, o título dos conjugados prontos para uso. Uma vez que alguns laboratórios não estão habituados a titular o conjugado contra um padrão absoluto ou consensual, um mesmo teste realizado em kits de marcas diferentes pode apresentar títulos divergentes. Isto se agrava com a heterogeneidade no poder de iluminação dos microscópios utilizados nos diversos laboratórios. Esses problemas, em seu conjunto, são responsáveis pela heterogeneidade de resultados entre os vários laboratórios e precisam ser mais bem discutidos.

Finalmente, ao longo dos anos, sentiu-se necessidade de revisar as associações clínicas dos diferentes padrões estabelecidos no II Consenso. Desse modo, o III Consenso Brasileiro para Pesquisa de Autoanticorpos em Células HEp-2 teve como propósito avaliar as dificuldades de implantação do II Consenso, ocorrido no ano de 2002, discutir estratégias para controlar a qualidade do ensaio e promover a atualização das associações clínicas dos padrões de fluorescência.

\section{Método de trabalho}

O III Consenso ocorreu em Goiânia nos dias 13 e 14 de abril de 2007, com a participação de pesquisadores e especialistas de diversos centros universitários e laboratórios clínicos de diferentes regiões do Brasil, com o propósito de discutir e aprovar as recomendações que visam a melhores padronização, interpretação e utilização do ensaio pelos clínicos. Representantes comerciais de diferentes empresas produtoras de insumos para realização do teste de PAAC-IFI em HEp-2 foram convidados como ouvintes.

Essa versão do consenso abordou os seguintes problemas: 1) a necessidade de controlar a qualidade do ensaio; 2 ) a definição de alguns aspectos controversos na classificação proposta no II Consenso; 3) o relato de novos padrões de fluorescência; e 4) a revisão das associações clínicas. Os problemas foram apresentados para os componentes da assembleia e discutidos amplamente com vistas à obtenção de consenso entre os diversos participantes. As discussões foram embasadas por prévia revisão da literatura referente aos diversos temas, bem como apresentação de dados próprios pelos participantes.

\section{Recomendações gerais}

A classificação da reatividade dos nucléolos quando em concomitância com padrão nuclear homogêneo passa a ser não-reagente. O III Consenso reitera a classificação atual dos padrões de fluorescência nos quatro compartimentos celulares (citoplasma, núcleo, nucléolo e aparelho mitótico). Ademais, foram feitas algumas definições para situações de possível ambiguidade ou indefinição. Nos casos em que o núcleo é uniformemente corado e não se destaca a região do nucléolo, os membros do III Consenso entendem que não há reatividade precípua contra o nucléolo, portanto, o mesmo deve ser descrito como "não-reagente". Obviamente, o nucléolo será também descrito como "não-reagente" nos casos em que o mesmo se mostrar não-corado. Quando da existência de um padrão nuclear, o nucléolo somente será descrito como "reagente" quando sua coloração sobressair sobre a coloração do núcleo. O exemplo do laudo do padrão nuclear homogêneo pode ser observado no painel inferior da Figura 1.

\section{Padrões mistos}

Foi retificada a definição de padrões mistos. Foram categorizados como padrões mistos todos os casos em que a coloração de compartimentos celulares distintos (núcleo, nucléolo, citoplasma ou aparelho mitótico) ou de diferentes padrões de fluorescência em um mesmo compartimento celular foi observada. Assim, por exemplo, o padrão NuMA-1 é considerado um padrão misto, pois cora o núcleo e o aparelho mitótico. Outro exemplo é representado por um soro com uma mistura de autoanticorpos que corem simultaneamente o núcleo com padrão pontilhado fino e padrão nuclear pontilhado centromérico.

\section{Padrão nuclear pontilhado com pontos isolados}

O III Consenso alterou a deliberação do II Consenso quanto à necessidade de subclassificação do número de pontos no padrão nuclear pontilhado do tipo pontos isolados. Não mais se recomenda a denominação "maior que 10 pontos por núcleo" e "menor que 10 pontos por núcleo". A deno- 


\begin{tabular}{ll} 
Tabela & $\begin{array}{l}\text { Padrões de PAAC-IFI em HEp-2, descrição, p } \\
\text { clínicas mais frequentes }\end{array}$ \\
\hline Padrões & Descrição \\
\hline & $\begin{array}{l}\text { O padrão é caracterizado por uma } \\
\text { fluorescência em toda a membrana nuclear } \\
\text { (podendo ser emitida com informação } \\
\text { adicional em aspecto contínuo ou }\end{array}$ \\
Nuclear tipo & $\begin{array}{l}\text { pontilhado). Não observamos fluorescência } \\
\text { em nucléolos e citoplasma; a célula em }\end{array}$ \\
membrana & $\begin{array}{l}\text { divisão em todos os estágios apresenta-se } \\
\text { não fluorescente. Não confundir com o antigo } \\
\text { padrão periférico observado em fígado de rato } \\
\text { onde o DNA de dupla hélice se encontrava } \\
\text { ancorado às proteínas da membrana nuclear, } \\
\text { dando seu aspecto característico. }\end{array}$ \\
\hline
\end{tabular}

\begin{tabular}{|c|c|c|}
\hline $\begin{array}{l}\text { Nuclear } \\
\text { homogêneo }\end{array}$ & $\begin{array}{l}\text { Nucleoplasma fluorescente de forma } \\
\text { homogênea e regular. Não é possível } \\
\text { distinguir a área de nucléolo e este é } \\
\text { considerado não reagente. Placa metafásica } \\
\text { cromossômica intensamente corada, de } \\
\text { aspecto hialino, com decoração homogênea } \\
\text { dos cromossomos, também positiva na } \\
\text { anáfase e telófase. Citoplasma normalmente } \\
\text { não fluorescente. }\end{array}$ & $\begin{array}{l}\text { Anticorpo anti-DNA nativo. Marcador de lúpus } \\
\text { eritematoso sistêmico. } \\
\text { Anticorpo anti-histona. Marcador de lúpus } \\
\text { eritematoso sistêmico induzido por drogas, } \\
\text { lúpus eritematoso sistêmico idiopático, artrite } \\
\text { reumatoide, artrite idiopática juvenil, importante } \\
\text { associação com uveíte na forma oligoarticular, } \\
\text { síndrome de felty e hepatite autoimune. }{ }^{(35,26)} \\
\text { Anticorpo anticromatina (DNA/histona, } \\
\text { nucleossomo). Lúpus eritematoso sistêmico. }{ }^{(3)}\end{array}$ \\
\hline $\begin{array}{l}\text { Nuclear } \\
\text { pontilhado } \\
\text { grosso }\end{array}$ & $\begin{array}{l}\text { Nucleoplasma com grânulos de aspecto } \\
\text { grosseiro, heterogêneos em tamanho e } \\
\text { brilho, sendo que sobressaem alguns poucos } \\
\text { grânulos maiores e mais brilhantes ( } 1 \text { a } 6 / \\
\text { núcleo) que correspondem ao corpo de Cajal, } \\
\text { rico em ribonucleoproteínas do spliceossomo. } \\
\text { Nucléolo, célula em divisão e citoplasma não } \\
\text { fluorescentes. }\end{array}$ & $\begin{array}{l}\text { Anticorpo anti-Sm. Marcador para lúpus eritematoso } \\
\text { sistêmico. }{ }^{(32,10)} \\
\text { Anticorpo anti-Rnp. Critério obrigatório no } \\
\text { diagnóstico da doença mista do tecido conjuntivo, } \\
\text { também presente no lúpus eritematoso sistêmico e } \\
\text { esclerose sistêmica. }{ }^{(32)}\end{array}$ \\
\hline $\begin{array}{l}\text { Nuclear } \\
\text { pontilhado } \\
\text { fino }\end{array}$ & $\begin{array}{l}\text { Nucleoplasma com granulação fina. } \\
\text { Nucléolo, célula em divisão e citoplasma não } \\
\text { fluorescentes. }\end{array}$ & $\begin{array}{l}\text { Anticorpo anti-SS-A/Ro. Síndrome de Sjögren } \\
\text { primária, lúpus eritematoso sistêmico, lúpus } \\
\text { neonatal e lúpus cutâneo subagudo, esclerose } \\
\text { sistêmica, polimiosite e cirrose biliar primária. }{ }^{(7)} \\
\text { Anticorpo anti-SS-B/La. Síndrome de Sjögren } \\
\text { primária, lúpus eritematoso sistêmico, lúpus } \\
\text { neonatal. }{ }^{(7)}\end{array}$ \\
\hline
\end{tabular}

Relevâncias clínicas por autoanticorpos

Anticorpo contra proteínas do envelope nuclear.

Cirrose biliar primária, hepatites autoimunes, raramente associado a doenças reumáticas. Algumas formas de lúpus eritematoso sistêmico e esclerodermia linear, síndrome do anticorpo antifosfolípide. Esse padrão pode ser observado em indivíduos sem evidência aparente de autoimunidade, principalmente quando em baixos títulos.

Anticorpo anti-gp210 é específico para cirrose biliar primária. Outros autoanticorpos associados a esse padrão: anti-p62 (nucleoporina), anti-lamin A, anti-lamin B, anti-lamin C, anti-LBP. ${ }^{(9)}$

Anticorpo anti-DNA nativo. Marcador de lúpus eritematoso sistêmico.

Anticorpo anti-histona. Marcador de lúpus eritematoso sistêmico induzido por drogas, lúpus eritematoso sistêmico idiopático, artrite reumatoide, artrite idiopática juvenil, importante associação com uveíte na forma oligoarticular, síndrome de felty e hepatite autoimune. ${ }^{(35,26)}$ Anticorpo anticromatina (DNA/histona, nucleossomo). Lúpus eritematoso sistêmico. ${ }^{(3)}$

Anticorpo anti-Sm. Marcador para lúpus eritematoso

Anticorpo anti-Rnp. Critério obrigatório no diagnóstico da doença mista do tecido conjuntivo, também presente no lúpus eritematoso sistêmico e esclerose sistêmica. ${ }^{(32)}$

(continuação da Tabela na próxima página) 
Padrões de PAAC-IFI em HEp-2, descrição, principais autoanticorpos associados e associações

Tabela

Padrões

\section{clínicas mais frequentes (continuação)}

Relevâncias clínicas por autoanticorpos

Anticorpo antiproteína p75 (cofator de trascrição) denominado LEDGF/p75. É um dos padrões mais

Nucleoplasma da célula em intérfase apresenta-se como um pontilhado peculiar, Nuclear de distribuição heterogênea, nucléolo não pontilhado fluorescente. A célula em divisão apresenta fino denso decoração em pontilhado intenso e grosseiro dos cromossomos na placa metafásica, com citoplasma não fluorescente. frequentes encontrados na rotina, cuja correlação clínica ainda não está bem estabelecida, sendo frequentemente encontrado em indivíduos sem evidência objetiva de doença sistêmica. Encontrado raramente em doenças reumáticas autoimunes, processos inflamatórios específicos e inespecíficos. Existem relatos na literatura do encontro desse padrão em pacientes com cistite intersticial, dermatite atópica, psoríase e asma. ${ }^{(33)}$

Nucleoplasma apresenta-se com pontos

Nuclear fluorescentes isolados (podendo ser fornecida pontilhado como informação adicional o numero de pontos isolados pontos maior ou igual a 10 ou menos do que 10 pontos por núcleo). Nucléolo, célula em divisão e citoplasma não fluorescentes.

\begin{tabular}{|c|c|}
\hline $\begin{array}{l}\text { Nuclear } \\
\text { pontilhado } \\
\text { centromérico }\end{array}$ & $\begin{array}{l}\text { Nucleoplasma da célula em intérfase, } \\
\text { apresentando-se pontilhado com um } \\
\text { número constante de } 46 \text { pontos. Nucléolo } \\
\text { normalmente não fluorescente, célula em } \\
\text { divisão apresenta concentração dos pontos } \\
\text { na placa metafásica. Citoplasma não } \\
\text { fluorescente. }\end{array}$ \\
\hline $\begin{array}{l}\text { Nuclear } \\
\text { pontilhado } \\
\text { pleomórfico }\end{array}$ & $\begin{array}{l}0 \text { nucleoplasma apresenta-se totalmente } \\
\text { não fluorescente na célula em fase G1 } \\
\text { da intérfase, passando a pontilhado com } \\
\text { grânulos variando de grosso, fino a fino denso } \\
\text { na medida em que a célula evolui para as } \\
\text { fases S e G2. Nucléolo e citoplasma não } \\
\text { fluorescentes. Esse padrão é sugestivo de } \\
\text { anticorpos anti-PCNA. }\end{array}$ \\
\hline
\end{tabular}

Anticorpo anti-p80 coilina. Não possui associação clínica definida. ${ }^{(4)}$

Anticorpo anti-Sp100 - anti-p95. Descrito

principalmente na cirrose biliar primária. ${ }^{(30)}$

Anticorpo anticentrômero (proteínas CENP-A, CENP-B e CENP-C). Esclerose sistêmica forma CREST (calcinose, fenômeno de Raynaud, disfunção motora do esôfago, esclerodactilia e telangiectasia), cirrose biliar primária e síndrome de Sjögren. Raramente observado em outras doenças autoimunes. Pode preceder a forma CREST por anos. ${ }^{(22,23)}$

\section{Anticorpo contra núcleo de células em proliferação} (Anti- PCNA). Encontrado especificamente em pacientes com lúpus eritematoso sistêmico. ${ }^{(36)}$
Nucleolar Nucléolo homogêneo, célula em divisão e homogêneo
Anticorpo anti-To/Th. Ocorre na esclerose sistêmica. ${ }^{(38)}$ Anticorpo antinucleolina. Muito raro, descrito no lúpus eritematoso sistêmico, doença enxerto versus hospedeiro e na mononucleose infecciosa. Anticorpo anti-B23 (nucleofosmina). Descrito na esclerose sistêmica, alguns tipos de câncer síndrome do anticorpo antifosfolípide e doença enxerto versus hospedeiro. 


\begin{tabular}{|c|c|c|}
\hline Tabela & \multicolumn{2}{|c|}{$\begin{array}{l}\text { Padrões de PAAC-IFI em HEp-2, descrição, principais autoanticorpos associados e associações } \\
\text { clínicas mais frequentes (continuação) }\end{array}$} \\
\hline Padrões & Descrição & Relevâncias clínicas por autoanticorpos \\
\hline $\begin{array}{l}\text { Nucleolar } \\
\text { aglomerado }\end{array}$ & $\begin{array}{l}0 \text { nucléolo se apresenta com grumos de } \\
\text { intensa fluorescência (como cachos de uva). } \\
\text { Citoplasma e núcleo não fluorescentes. A } \\
\text { célula em divisão apresenta-se amorfa, com } \\
\text { coloração delicada em volta dos cromossomos } \\
\text { da placa metafásica. }\end{array}$ & $\begin{array}{l}\text { Anticorpo antifibrilarina (U3-nRNP). Associado } \\
\text { à esclerose sistêmica, especialmente com } \\
\text { comprometimento visceral grave, entre elas a } \\
\text { hipertensão pulmonar. }{ }^{(34)}\end{array}$ \\
\hline $\begin{array}{l}\text { Nucleolar } \\
\text { pontilhado }\end{array}$ & $\begin{array}{l}\text { Decoração pontilhada nucleolar e } 5 \text { a } 10 \\
\text { pontos distintos e brilhantes ao longo da } \\
\text { placa metafásica cromossômica. Núcleo e } \\
\text { citoplasma não corados. }\end{array}$ & $\begin{array}{l}\text { Anticorpo anti-NOR 90. Inicialmente descrito na } \\
\text { esclerose sistêmica. Atualmente descrito em } \\
\text { outras doenças do tecido conjuntivo, porém sem } \\
\text { relevância clínica definida. }{ }^{\left({ }^{4}\right)} \\
\text { Anticorpo anti-RNA polimerase I. Esclerose } \\
\text { sistêmica de forma difusa com tendência para } \\
\text { comprometimento visceral mais frequente e grave. }{ }^{(34)} \\
\text { Anticorpo anti-ASE (anti-sense to ERCC-1). } \\
\text { Frequentemente encontrado em associação a } \\
\text { anticorpos anti-NOR-90. A associação mais } \\
\text { frequente parece ser o lúpus eritematoso sistêmico. }\end{array}$ \\
\hline $\begin{array}{l}\text { Citoplasmático } \\
\text { fibrilar linear }\end{array}$ & $\begin{array}{l}\text { Fibras de estresses que constituem o } \\
\text { citoesqueleto decoradas de forma retilínea, } \\
\text { cruzando toda a extensão da célula e não } \\
\text { respeitando os limites nucleares. Núcleos e } \\
\text { nucléolos não fluorescentes. }\end{array}$ & $\begin{array}{l}\text { Anticorpo antiactina. Encontrado em hepatopatias: } \\
\text { hepatite autoimune, cirrose. } \\
\text { Anticorpo antimiosina. Hepatite C, hepato-carcinoma, } \\
\text { miastenia gravis. Quando em títulos baixos ou moderados } \\
\text { podem não ter relevância clínica definida. } \text {. }^{(1,28)}\end{array}$ \\
\hline $\begin{array}{l}\text { Citoplasmático } \\
\text { fibrilar } \\
\text { filamentar }\end{array}$ & $\begin{array}{l}\text { Decoração de filamentos com acentuação uni } \\
\text { ou bipolar em relação à membrana nuclear. } \\
\text { Núcleos e nucléolos não fluorescentes. }\end{array}$ & $\begin{array}{l}\text { Anticorpo antivimentina e antiqueratina. Anticorpo } \\
\text { antiqueratina é o anticorpo mais importante em } \\
\text { doença hepática alcoólica. Descritos em várias } \\
\text { doenças inflamatórias e infecciosas. Quando } \\
\text { em títulos baixos ou moderados podem não ter } \\
\text { relevância clínica definida. }{ }^{(27)}\end{array}$ \\
\hline $\begin{array}{l}\text { Citoplasmático } \\
\text { fibrilar } \\
\text { segmentar }\end{array}$ & $\begin{array}{l}\text { Apenas segmentos curtos das fibras de } \\
\text { estresse se encontram fluorescentes. Núcleo } \\
\text { e nucléolos negativos. Nas células em } \\
\text { divisão, podemos observar eventualmente } \\
\text { múltiplos grânulos intensamente } \\
\text { fluorescentes que correspondem à forma } \\
\text { globular das proteínas do citoplasma. }\end{array}$ & $\begin{array}{l}\text { Antialfa-actinina, antivinculina e antitropomiosina. } \\
\text { Anticorpos encontrados na miastenia gravis, } \\
\text { doença de Crohn e colite ulcerativa. Quando } \\
\text { em títulos baixos ou moderados podem não ter } \\
\text { relevância clínica definida. }{ }^{(27)}\end{array}$ \\
\hline $\begin{array}{l}\text { Citoplasmático } \\
\text { pontilhado } \\
\text { polar }\end{array}$ & $\begin{array}{l}\text { Esse também é um laudo obrigatório, pois } \\
\text { evidencia cisternas do aparelho de Golgi. } \\
\text { A decoração é apenas citoplasmática em } \\
\text { pontos agrupados de situação perinuclear, } \\
\text { normalmente em apenas um pólo nuclear. } \\
\text { Núcleo, nucléolo e célula em divisão não } \\
\text { fluorescentes. }\end{array}$ & $\begin{array}{l}\text { Anticorpo antigolginas (cisternas do aparelho de Golgi). } \\
\text { Raro no lúpus eritematoso sistêmico, síndrome } \\
\text { de Sjögren primária e outras doenças autoimunes } \\
\text { sistêmicas. Relatado em ataxia cerebelar idiopática, } \\
\text { degeneração cerebelar paraneoplásica e infecções } \\
\text { virais pelo vírus Epstein Barr (EBV) e pelo vírus da } \\
\text { imunodeficiência humana (HIV). Quando em títulos } \\
\text { baixos ou moderados podem não ter relevância } \\
\text { clínica definida. }{ }^{(31,40)}\end{array}$ \\
\hline
\end{tabular}




\begin{tabular}{|c|c|c|}
\hline Tabela & \multicolumn{2}{|c|}{$\begin{array}{l}\text { Padrões de PAAC-IFI em HEp-2, descrição, principais autoanticorpos associados e associações } \\
\text { clínicas mais frequentes (continuação) }\end{array}$} \\
\hline Padrões & Descrição & Relevâncias clínicas por autoanticorpos \\
\hline $\begin{array}{l}\text { Citoplasmático } \\
\text { pontilhado } \\
\text { pontos } \\
\text { isolados }\end{array}$ & $\begin{array}{l}\text { Pontos definidos de número variável por toda } \\
\text { a extensão do citoplasma. Núcleo, nucléolo e } \\
\text { célula em divisão não fluorescentes. }\end{array}$ & $\begin{array}{l}\text { Anticorpo anti-EEA1 e antifosfatidilserina. Não há } \\
\text { associações clínicas bem definidas. } \\
\text { Anticorpo anti-GWB. Associado à síndrome Sjögren } \\
\text { primária, embora observado também em diversas } \\
\text { outras condições clínicas. }{ }^{(18)}\end{array}$ \\
\hline $\begin{array}{l}\text { Citoplasmático } \\
\text { pontilhado } \\
\text { fino denso }\end{array}$ & $\begin{array}{l}\text { Fluorescência de pontos finos, densos e } \\
\text { confluentes, chegando à quase homogeneidade. } \\
0 \text { núcleo não está corado, mas pode ou não } \\
\text { apresentar uma leve decoração homogênea na } \\
\text { área do nucléolo. A célula em divisão é não } \\
\text { fluorescente. No caso de haver fluorescência } \\
\text { concomitante de citoplasma e nucléolo, o } \\
\text { padrão é classificado como misto. }\end{array}$ & $\begin{array}{l}\text { Anticorpo anti-PL7/PL12. Esse padrão de } \\
\text { fluorescência pode raramente estar associado a } \\
\text { anticorpos encontrados na polimiosite. }{ }^{(38)} \\
\text { Anticorpo antiproteína P-ribossomal. Esse } \\
\text { padrão ocorre no lúpus eritematoso sistêmico } \\
\text { e está particularmente associado ao anticorpo } \\
\text { antiproteína P-ribossomal. }{ }^{(8)}\end{array}$ \\
\hline $\begin{array}{l}\text { Citoplasmático } \\
\text { pontilhado } \\
\text { fino }\end{array}$ & $\begin{array}{l}\text { Pontos definidos em grande número e } \\
\text { densidade, célula em divisão e nucléolo não } \\
\text { fluorescentes. }\end{array}$ & $\begin{array}{l}\text { Anticorpo anti-histidil t RNA sintetase (Jo1). } \\
\text { Anticorpo marcador de polimiosite no adulto. } \\
\text { Descrito raramente na dermatomiosite. Outros } \\
\text { anticorpos anti-tRNA sintetases podem gerar } 0 \\
\text { mesmo padrão. }{ }^{\text {(38) }}\end{array}$ \\
\hline $\begin{array}{l}\text { Citoplasmático } \\
\text { pontilhado } \\
\text { reticulado }\end{array}$ & $\begin{array}{l}\text { Fluorescência em múltiplos pontos dispostos sob } \\
\text { forma de retículo irradiando a partir da periferia } \\
\text { do núcleo por todo o citoplasma. Núcleo, } \\
\text { nucléolo e célula em divisão não fluorescentes. }\end{array}$ & $\begin{array}{l}\text { Anticorpo antimitocôndria. Marcador da cirrose } \\
\text { biliar primária. Raramente encontrado na esclerose } \\
\text { sistêmica. Devido ao encontro relativamente } \\
\text { comum de padrão assemelhado e não relacionado } \\
\text { a anticorpos antimitocôndria, é fundamental a } \\
\text { confirmação por teste específico. }{ }^{(2,11)}\end{array}$ \\
\hline $\begin{array}{l}\text { Aparelho } \\
\text { mitótico tipo } \\
\text { centríolo }\end{array}$ & $\begin{array}{l}\text { Ponto fluorescente isolado no citoplasma em } \\
\text { um polo na célula em repouso (intérfase) que } \\
\text { se divide em dois e migra ao polo oposto do } \\
\text { núcleo à medida que a célula entra em divisão. }\end{array}$ & $\begin{array}{l}\text { Anticorpo antialfa-enolase. Em baixos títulos não } \\
\text { têm associação clínica definida. Em altos títulos } \\
\text { pode estar associado à esclerose sistêmica. }{ }^{(16)}\end{array}$ \\
\hline $\begin{array}{l}\text { Aparelho } \\
\text { mitótico } \\
\text { tipo ponte } \\
\text { intercelular }\end{array}$ & $\begin{array}{l}\text { Antígenos que formam a união entre células } \\
\text { mãe/filha ao final da telófase. Podem ser } \\
\text { observados com fluorescência intensa na } \\
\text { ponte citoplasmática que sofrerá clivagem ao } \\
\text { final da divisão celular. }\end{array}$ & $\begin{array}{l}\text { Anticorpo antibeta-tubulina. Podem ser encontrados } \\
\text { no lúpus eritematoso sistêmico e na doença mista } \\
\text { do tecido conjuntivo. Outros anticorpos ainda } \\
\text { não bem definidos podem gerar o mesmo padrão. } \\
\text { Associado a diversas condições autoimunes com } \\
\text { baixa especificidade tendo relevância clínica } \\
\text { somente em altos títulos. }{ }^{(5)}\end{array}$ \\
\hline $\begin{array}{l}\text { Aparelho } \\
\text { mitótico tipo } \\
\text { fuso mitótico } \\
\text { (NuMa-2) }\end{array}$ & $\begin{array}{l}\text { Células em intérfase se encontram não } \\
\text { fluorescentes em todas as suas estruturas. } \\
\text { Há decoração extensa e grosseira nos } \\
\text { pólos mitóticos das células em metáfase } \\
\text { e as pontes intercelulares são positivas na } \\
\text { telófase. Citoplasma não fluorescente. }\end{array}$ & $\begin{array}{l}\text { Anticorpo anti-HsEg5/NuMA-2. Associado a } \\
\text { diversas condições autoimunes com baixa } \\
\text { especificidade, tendo relevância clínica somente } \\
\text { em altos títulos. }{ }^{(39)}\end{array}$ \\
\hline
\end{tabular}




\begin{tabular}{|c|c|c|}
\hline Tabela & \multicolumn{2}{|c|}{$\begin{array}{l}\text { Padrões de PAAC-IFI em HEp-2, descrição, principais autoanticorpos associados e associações } \\
\text { clínicas mais frequentes (continuação) }\end{array}$} \\
\hline Padrões & Descrição & Relevâncias clínicas por autoanticorpos \\
\hline $\begin{array}{l}\text { Misto do } \\
\text { tipo nuclear } \\
\text { pontilhado } \\
\text { fino com } \\
\text { fluorescência } \\
\text { do aparelho } \\
\text { mitótico }\end{array}$ & $\begin{array}{l}\text { As células em intérfase apresentam o } \\
\text { núcleo corado como um pontilhado bem } \\
\text { fino, geralmente em alto título. Células } \\
\text { mitóticas em metáfase e anáfase apresentam } \\
\text { colocação bem definida e delicada da região } \\
\text { pericentrossômica e das partes proximais do } \\
\text { fuso mitótico. Na telófase já se vê novamente } \\
\text { a coloração pontilhada dos núcleos } \\
\text { neoformados e não se vê coloração da ponte } \\
\text { intercelular. }\end{array}$ & $\begin{array}{l}\text { Anticorpo anti-NuMa1. Associado à síndrome de } \\
\text { Sjögren, podendo ocorrer também em outras } \\
\text { condições autoimunes ou inflamatórias crônicas. } \\
\text { Quando em títulos baixos ou moderados, pode não } \\
\text { estar associado à evidência objetiva de doença } \\
\text { inflamatória sistêmica. }{ }^{(5)}\end{array}$ \\
\hline $\begin{array}{l}\text { Misto do } \\
\text { tipo nuclear } \\
\text { pontilhado } \\
\text { grosso e } \\
\text { nucleolar } \\
\text { homogêneo } \\
\end{array}$ & $\begin{array}{l}\text { Células em intérfase apresentam o núcleo } \\
\text { corado como pontilhado grosso e o nucléolo } \\
\text { corado de forma homogênea. Na metáfase há } \\
\text { coloração ao redor da placa metafásica. }\end{array}$ & $\begin{array}{l}\text { Anticorpo anti-KU. Marcador de superposição, } \\
\text { polimiosite e esclerose sistêmica. Podem ocorrer } \\
\text { no lúpus eritematoso sistêmico e esclerodermia. }{ }^{(20)}\end{array}$ \\
\hline $\begin{array}{l}\text { Misto do } \\
\text { tipo nuclear } \\
\text { e nucleolar } \\
\text { pontilhado } \\
\text { fino com placa } \\
\text { metafásica } \\
\text { corada }\end{array}$ & $\begin{array}{l}\text { Células em intérfase apresentam o núcleo } \\
\text { corado de forma pontilhada fina e o nucléolo } \\
\text { sobressai também com padrão pontilhado } \\
\text { fino. Na metáfase, a placa metafásica } \\
\text { apresenta padrão pontilhado fino. }\end{array}$ & $\begin{array}{l}\text { Anticorpo anti-DNA topoisomerase I (Scl-70). } \\
\text { Associado a esclerose sistêmica forma difusa, em } \\
\text { que indica formas de maior comprometimento } \\
\text { visceral. Mais raramente pode ocorrer na síndrome } \\
\text { CREST e superposição. }{ }^{(25)}\end{array}$ \\
\hline $\begin{array}{l}\text { Misto do } \\
\text { tipo nuclear } \\
\text { pontilhado } \\
\text { fino e } \\
\text { nucleolar } \\
\text { pontilhado }\end{array}$ & $\begin{array}{l}\text { Células em intérfase apresentam o núcleo } \\
\text { corado de forma pontilhada fina delicada e } \\
\text { sobressaindo o nucléolo corado com padrão } \\
\text { pontilhado (pontos individuais). } 0 \text { citoplasma } \\
\text { não é corado. Na metáfase, observam-se } \\
\text { cinco a } 10 \text { pontos isolados e brilhantes na } \\
\text { placa metafásica, correspondentes às regiões } \\
\text { organizadoras de nucléolo (NOR). }\end{array}$ & $\begin{array}{l}\text { Anticorpos anti-RNA polimerase I e II. Esses } \\
\text { dois autoanticorpos usualmente aparecem em } \\
\text { combinação, sendo a RNA pol I responsável pela } \\
\text { distribuição nucleolar e em NOR, enquanto a RNA } \\
\text { pol II responde pela distribuição nuclear. Anti-RNA } \\
\text { pol I é considerado marcador de esclerose sistêmica } \\
\text { e anti-RNA pol II aparece em diversas condições } \\
\text { autoimunes. }{ }^{(25)}\end{array}$ \\
\hline $\begin{array}{l}\text { Misto do tipo } \\
\text { citoplasmático } \\
\text { pontilhado } \\
\text { fino denso a } \\
\text { homogêneo } \\
\text { e nucleolar } \\
\text { homogêneo }\end{array}$ & $\begin{array}{l}0 \text { núcleo é totalmente não corado e o } \\
\text { nucléolo é corado fracamente. } 0 \text { citoplasma } \\
\text { apresenta intensa coloração com pontilhado } \\
\text { muito fino e muito denso, quase homogêneo. } \\
\text { As células mitóticas não são coradas. }\end{array}$ & $\begin{array}{l}\text { Anticorpo anti-rRNP (antiproteína P ribossomal). } \\
\text { Marcador de lúpus eritematoso sistêmico e mais } \\
\text { frequentemente relacionado à psicose lúpica. } \\
\text { Também parece estar associado à atividade da } \\
\text { doença. }{ }^{(8,24)}\end{array}$ \\
\hline
\end{tabular}

minação do padrão ficou estabelecida como "padrão nuclear pontilhado do tipo pontos isolados". Essa mudança decorre do fato de que o número de corpos nucleares corados por anticorpos anti-p80-coilina e anti-sp-100 sofre considerável variação conforme o substrato celular em uso. Embora o observador experiente consiga, na maioria dos casos, sugerir com segurança o autoanticorpo mais provável, o número de pontos por núcleo não é um critério absoluto. Esta alteração foi implementada na árvore de classificação dos padrões nucleares, conforme pode ser observado na Figura 2. 


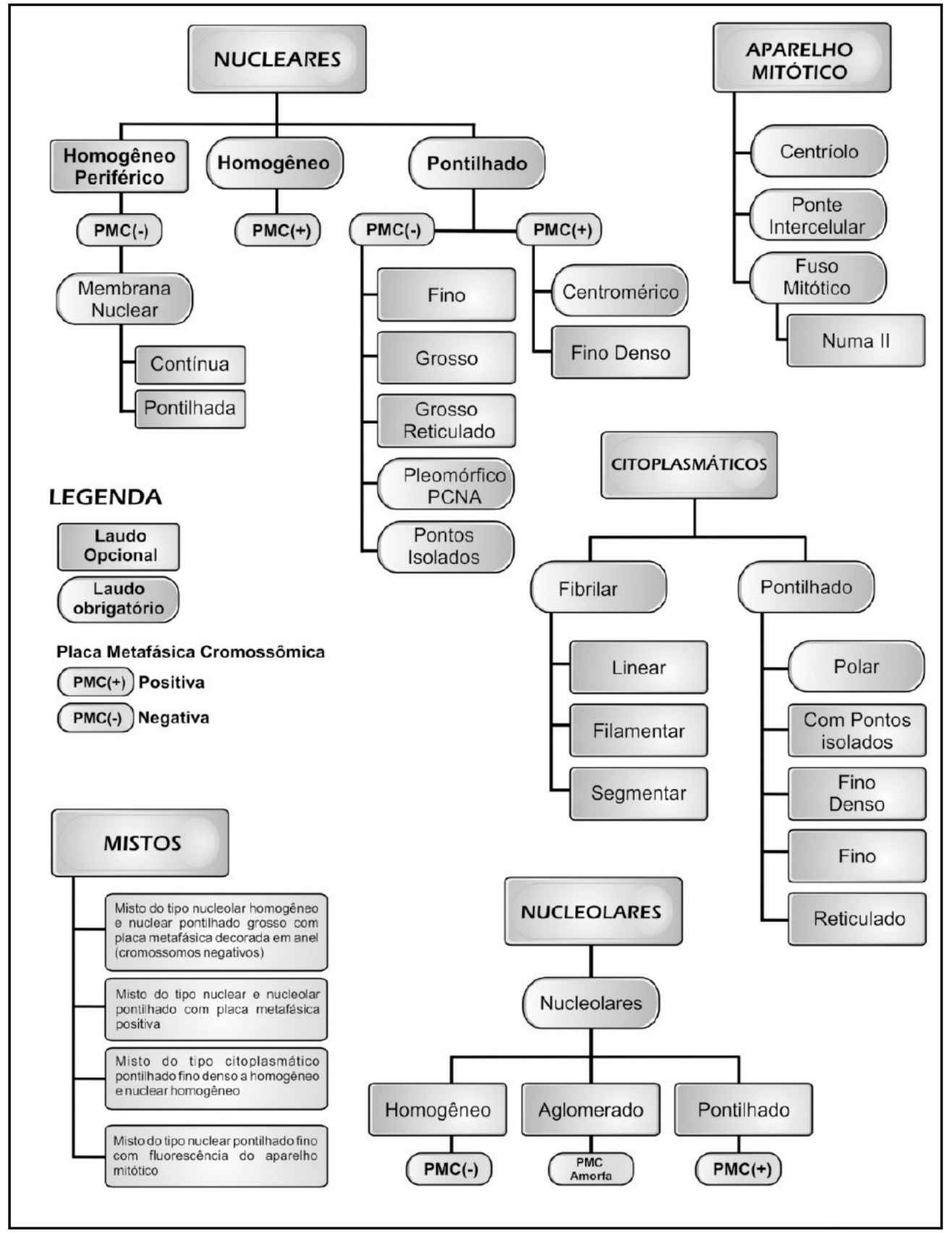

Figura 2 - Árvores de classificação dos padrões nucleares, nucleolares, citoplasmáticos, do aparelho mitótico e mistos

\section{Padrões não-caracterizados ou com características novas}

O III Consenso reconhece que há padrões não caracterizados ou com características não-definidas, conforme a classificação existente. Nesses casos, a recomendação é que se descreva morfologicamente o padrão observado, que se acrescente uma observação especificando que o mesmo não faz parte da nomenclatura do consenso e que suas associações imunológicas e clínicas ainda não estão definidas. Recomenda-se fortemente que o suposto novo padrão seja testado e confirmado em kit comercial de marca diferente daquela em que originalmente se observou o padrão, evitando assim que condições artefatuais induzam uma falsa interpretação.

Dois novos padrões de fluorescência foram comunicados por participantes do III consenso e vários outros membros testemunharam já haver observado esses padrões. O primeiro refere-se a um padrão nuclear pontilhado fino, aproximando-se da textura homogênea e com placa metafásica corada da mesma forma. Sua associação clínica e identidade imunológica não estão definidas. Sua importância deriva do fato de que pode ser facilmente confundido com o 
padrão pontilhado fino denso e com o padrão homogêneo (Figura 3). O segundo refere-se a um padrão citoplasmático em forma de pequenos bastões (rods) e círculos (rings) que, aparentemente, está associado à infecção pelo vírus da hepatite C (HCV). Há estudos em curso por alguns grupos de pesquisa com a finalidade de estabelecer sua identidade imunológica (Figura 4). Como ainda não estão definitivamente caracterizados, esses dois novos padrões foram considerados preliminares e o III Consenso recomendou que os mesmos fossem completamente caracterizados e apresentados na próxima versão do consenso.

\section{Substratos à base de células geneticamente modificadas}

O III Consenso não realizou estudos sistematizados com substratos geneticamente modificados, sendo este estudo possível objeto de debate nos próximos encontros.

\section{Controle de qualidade}

O III Consenso recomenda e incentiva a busca por programas de controle de qualidade. Essa recomendação visa fazer frente às dificuldades em garantir a qualidade do teste, dada a necessidade de profissionais com treinamento especializado, heterogeneidade dos kits comerciais e não-padronização de equipamentos ópticos entre laboratórios. Entre os programas de qualidade institucionais, foram citados o do College Of American Pathologists (CAP) e o programa educativo PAAC-IFI em HEp-2 da Controlab. Também foram citados programas e reagentes para controle de qualidade de em-

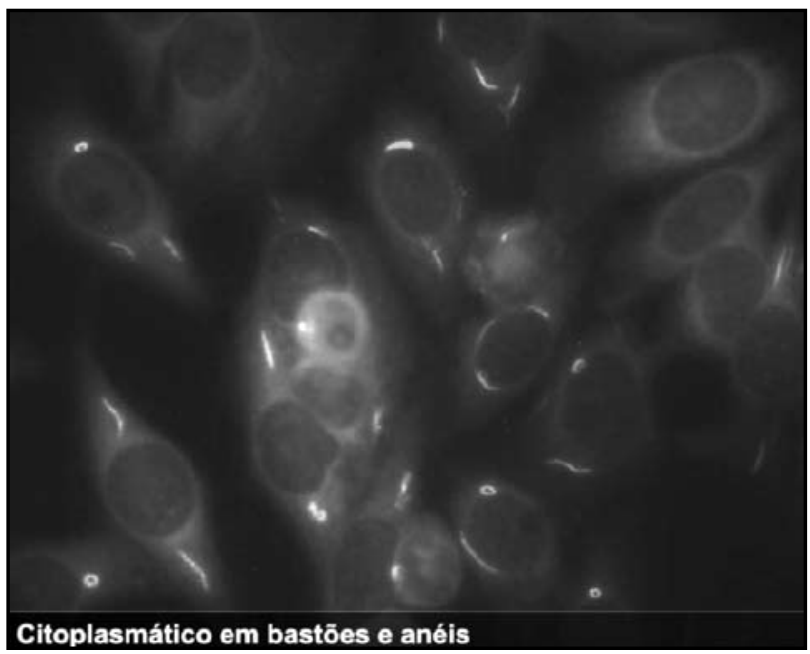

Figura 4 - Padrão citoplasmático com fluorescência em forma de bastões e anéis (rods and rings). Aparentemente associado à infecção pelo HCV e tratamento com interferon. Os antígenos alvos desses anticorpos ainda estão sendo definidos
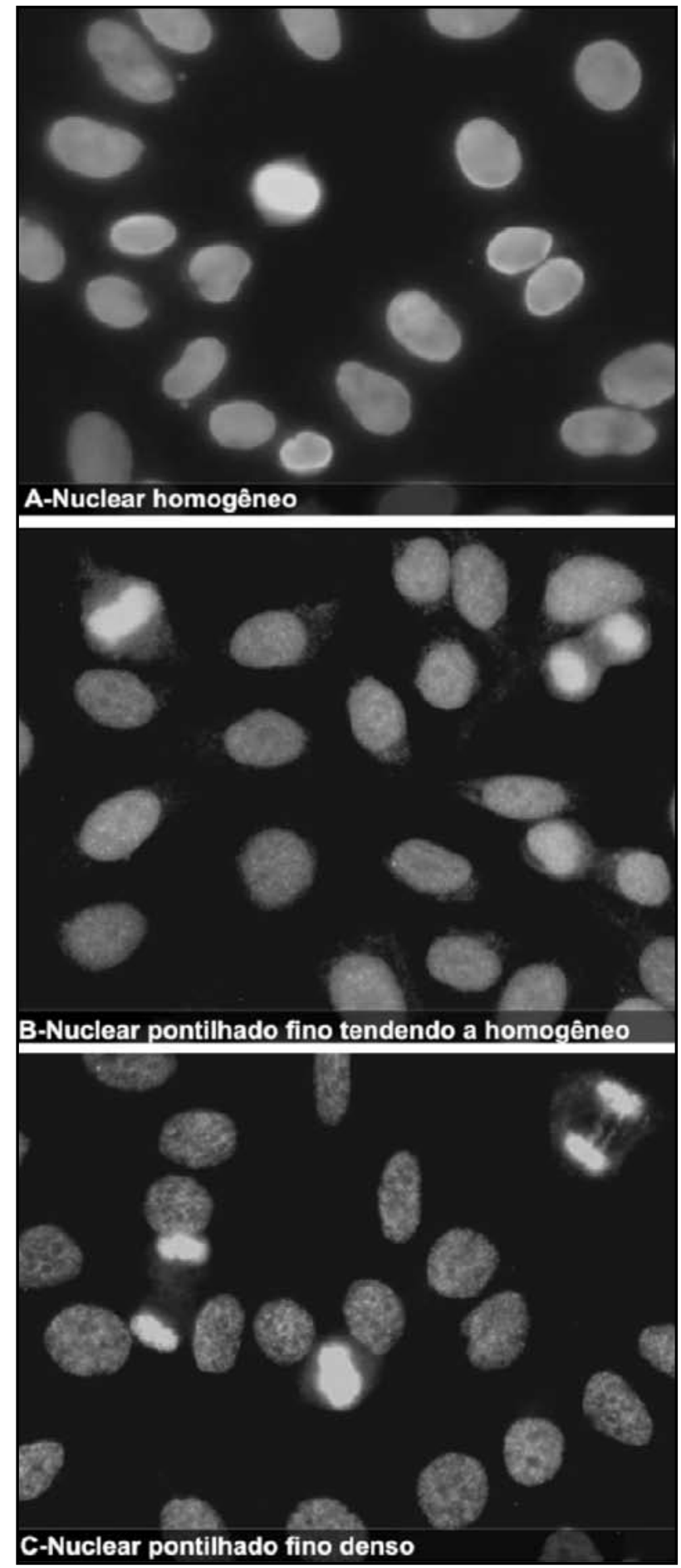

Figura 3 - Padrão nuclear pontilhado fino tendendo a homogêneo (B). As células apresentam nucleoplasma com textura de tendência homogênea e placa metafásica corada. Pode ser confundido com o padrão nuclear pontilhado findo denso (C), porém não é positivo para a proteína de $75 \mathrm{Kda}$ e para ser observado o padrão nuclear homogêneo. Imagens obtidas por imunofluorescência indireta em células Hep-2

presas privadas, como o PCQAUTO da GMK Diagnósticos, o Conexão HEp-2 da Hemagen Diagnósticos e a lâmina FITC-QC® da ALKA Tecnologia em Diagnósticos. 
Um ponto considerado fundamental pelos membros do consenso foi a necessidade de realização da titulação do conjugado por parte dos laboratórios como medida essencial para ajustar a quantidade do ensaio. Esta medida foi formalmente recomendada e teve como objetivo adequar a orientação do I Consenso, que sugeria a diluição de 1/40 como triagem, o que gerou muita dúvida em sua execução, tendo em vista a heterogeneidade de equipamentos para a leitura do teste nos laboratórios. Visando adequar essa inconformidade, o III Consenso recomenda como etapa primordial para a realização do controle de qualidade a titulação do conjugado a partir do uso de soros de referência. A titulação do conjugado com base no soro de referência permite equiparar os resultados obtidos em diferentes serviços utilizando microscópios com diferente potência da lâmpada. Foi ressaltado ainda que esse procedimento deve ser realizado para cada novo kit de lote diferente. A manutenção dessa titulação nos kits do mesmo lote pode ser realizada a partir do uso de controles de baixa intensidade. Nesse quesito, ressalta-se a utilidade de lâminas comerciais com microesferas pré-calibradas para diversas intensidades de fluorescência e que podem ser utilizadas para treinamento e calibração interna da leitura. Para promover a melhoria na qualidade dos diversos serviços e garantir a obtenção de resultados fidedignos, o III Consenso recomenda adesão de todos os laboratórios aos programas de controle de qualidade.

É de fundamental importância recordar que a reação de IFI depende de cinco fatores: o sistema óptico (microscópio), a potência da lâmpada (20, 50 ou $100 \mathrm{~W})$, a concentração do conjugado, os soros controles de reatividade mínima $(1 / 80)$ e o observador.

A concentração do conjugado permite equiparar sistemas ópticos diferentes, lâmpadas de potências diferentes e a capacidade de interpretação do observador, por exemplo: se a potência da lâmpada é baixa, é recomendada a utilização de um conjugado mais concentrado para se obter a mesma fluorescência de uma lâmpada de potência maior. Para estabelecer a concentração ideal do conjugado (título do conjugado), devemos utilizar a técnica de titulação em bloco em que várias diluições do conjugado são cruzadas com diversas concentrações de um soro de referência, procurando a maior diluição do conjugado capaz de reproduzir o título nominal do soro de referência.

O soro de referência pode acompanhar o kit pronto e o laboratório passará a se referenciar a sistema óptico, lâmpada e leitor, de acordo com o padrão estabelecido pelo fabricante. O soro de referência pode também ser adquirido comercialmente, obtido de instituições de controle de qualidade ou ainda o laboratório poderá enviar o seu soro a um outro laboratório de sua referência e, de posse dos resultados, passar a se referenciar a esse laboratório. Uma vez feita a primeira referência, ele poderá armazenar semanalmente alíquotas de soros de títulos determinados no próprio laboratório. $\mathrm{O}$ procedimento de titulação do conjugado está representado na Figura 5.

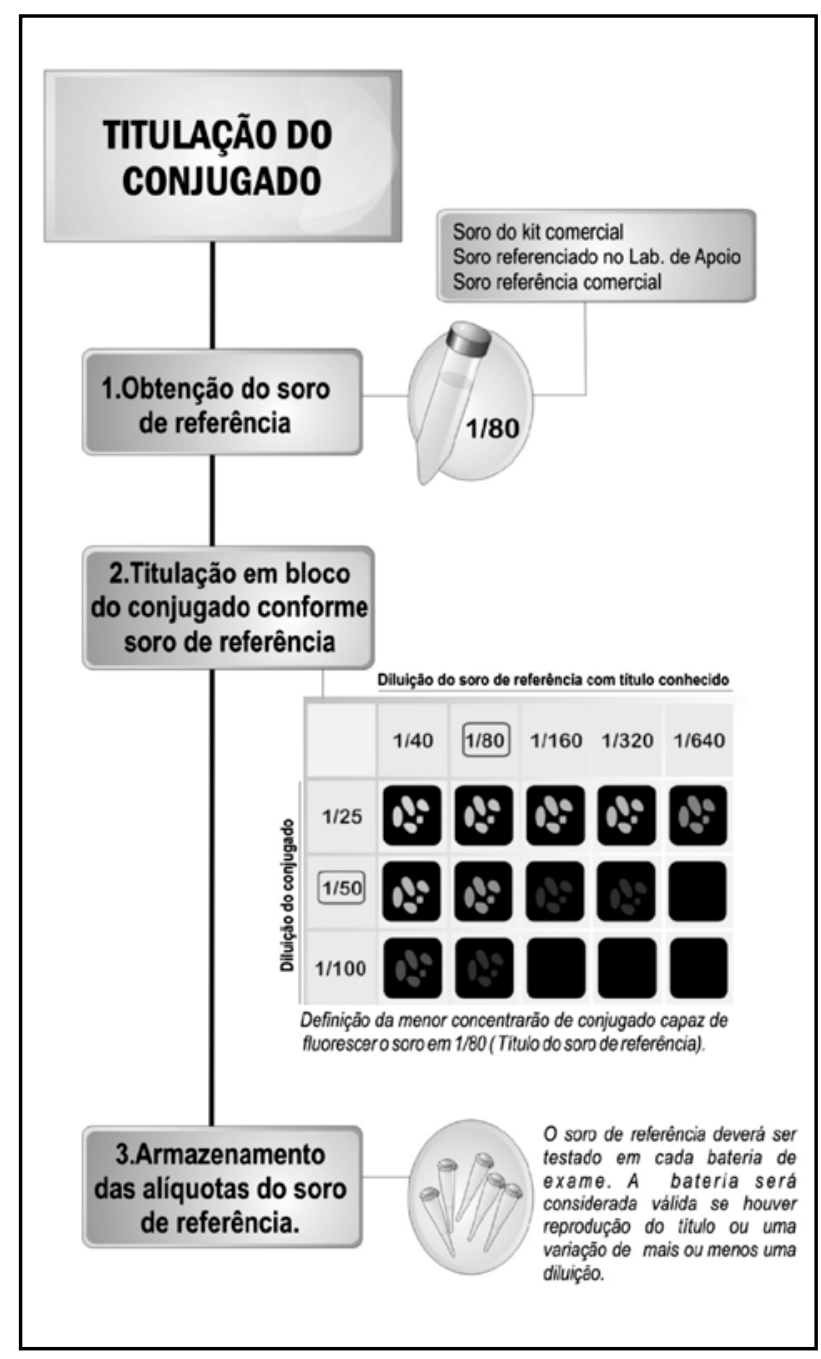

Figura 5 - Representação esquemática da titulação do conjugado

É recomendado que o laboratório mantenha em sua soroteca amostras para controle com título de reatividade mínima (por exemplo: $1 / 80$ ), a serem diluídas em 1/40, 1/80, 1/160 e 1/320. A cada bateria diária o laboratório deverá processar o controle baixo e deverá considerar a bateria válida se a variação de títulos for de mais ou menos uma diluição. Se for observada inconformidade do controle, por exemplo se uma amostra com título médio de $1 / 80$ apresentar-se como 
negativa, a bateria deverá ser invalidada. Utilizando o controle de reatividade mínima (1/80), uma bateria de testes somente será validada com a leitura de um título a mais ou a menos de 80 . No caso de ocorrer queda superior a um título, é provável que o sistema tenha entrado em instabilidade. Recomenda-se, então, que seja verificado primeiramente se houve problema na alíquota armazenada, nesse caso repetindo o teste com a alíquota armazenada na semana anterior. Se ao término da repetição o título encontrado foi o previsto, chegaremos à conclusão de que a alíquota do controle em uso havia se deteriorado. Se a nova alíquota apresentou também queda do título de mais de uma diluição, deveremos checar o sistema óptico (deterioração do filtro UV, inundação da objetiva com glicerina tamponada e desempenho da lâmpada). Caso não seja encontrada alteração nesses componentes e no número de horas de uso da lâmpada, a causa mais provável será degradação do conjugado, que deve então ser submetido a novo processo de titulação, como descrito anteriormente. Na Figura 6 está representado o fluxograma do controle de qualidade diário das reações.

Como recomendações importantes para manutenção do controle de qualidade adequado temos:

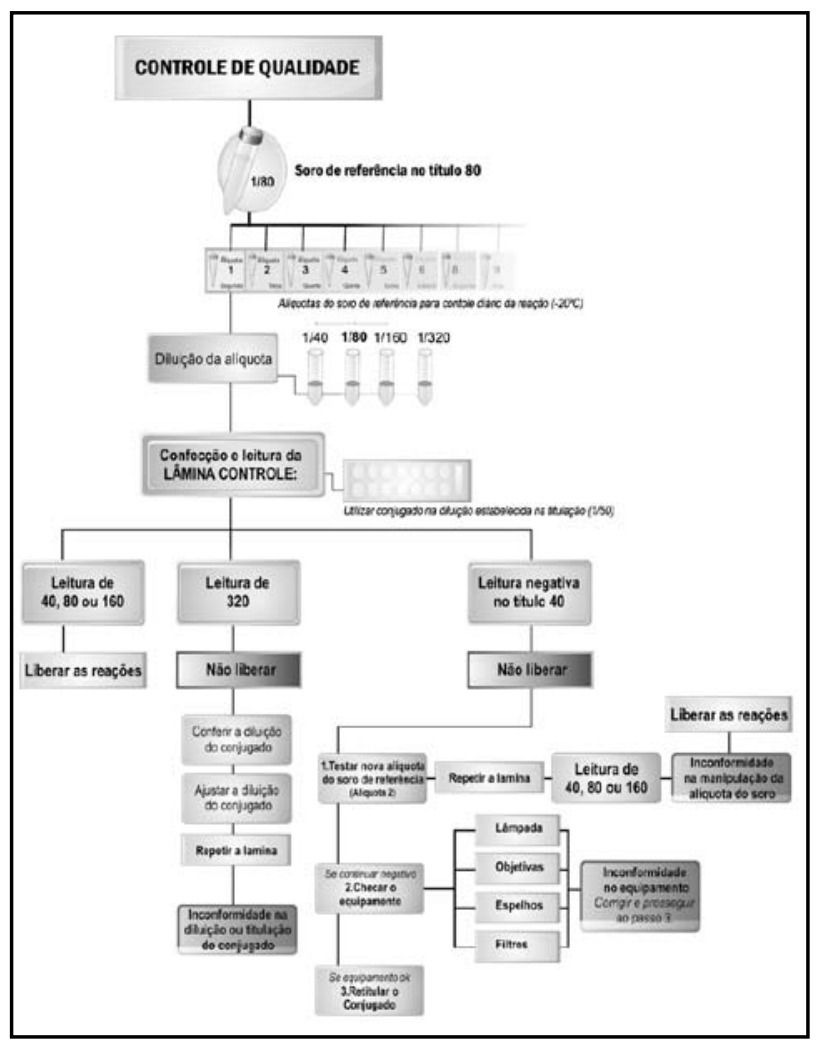

Figura 6 - Fluxograma geral do controle de qualidade das reações
- a realização do controle do conjugado a cada 15 dias e nova titulação sempre que um novo kit for aberto;

- checagem rotineira das objetivas e dos filtros do microscópio que interferem na definição do título do conjugado;

- além da checagem do tempo de lâmpada, é necessário checar se a lâmpada está centrada. Isso pode ser feito utilizando uma folha de papel branca colocada na mesa do microscópio e observado com objetiva de 10 se a lâmpada está centrada. Caso seja observado escurecimento de parte do campo, o manuseio dos botões de centragem direita e esquerda, superior e inferior e foco da lâmpada deverão ser acionados a fim de realizar o ajuste.

\section{Associações clínicas e descrição dos padrões}

O III Consenso conduziu ampla discussão para validação e reavaliação das associações clínicas e imunológicas referentes aos padrões de PAAC-IFI em HEp-2. As recomendações advindas dessa atividade estão listadas na Tabela anterior.

Em sua vasta maioria, as associações anteriormente descritas foram acordadas por unanimidade entre os participantes do consenso. Nos raros casos em que não houve unanimidade, acatou-se a opinião majoritária.

Essa iniciativa reflete a vigorosa atividade de pesquisa no campo de autoanticorpos em geral, e de anticorpos antinúcleo em particular, em nosso país. Deve ser enfatizado que essa atividade tem proporcionado uma evolução progressiva e marcante de nossa comunidade científica e profissional, firmando uma posição nacional independente com relação à forma de realizar e interpretar o ensaio para determinação de autoanticorpos em células HEp-2. Essa característica tem beneficiado também os clínicos que lançam mão desse exame laboratorial e, por conseguinte, os pacientes que a eles recorrem. Finalmente, é necessário que fique claro que esse é um processo de amadurecimento contínuo e progressivo e que o mesmo depende da interação de toda a comunidade envolvida com as várias etapas do processo.

\section{Agradecimentos}

Às sociedades Brasileira de Reumatologia (SBR), Brasileira de Patologia Clínica e Medicina Laboratorial (SBPC), Brasileira de Análises Clínicas (SBAC) e ao Conselho Regional de Biomedicina da $3^{\text {a }}$ região (CBRM-3). 


\section{Referências}

1. AGARWAL, N. et al. A study of autoimmune markers in hepatitis C infection. Indian J Med Res, v. 113, p. 170-4, 2001.

2. ALDERUCCIO, F. et al. Identification and characterization of mitochondria autoantigens in progressive systemic sclerosis: identily with the 72,000 Dalton autoantigen in primary biliary cirrhosis. J Immunol, v. 137, n. 6, p. 1855-9, 1986.

3. AMOURA, Z. et al. Presence of antinucleosome autoantibodies in a restricted set of connective tissue diseases: antinucleosome antibodies of the IgG3 subclass are markers of renal pathogenicity in systemic lupus erythematosus. Arthritis Rheum, v. 43, n. 1, p. 76-84, 2000.

4. ANDRADE, L. E. C. et al. Human autoantibody to a novel protein of the nuclear coiled body: immunological characterization and cDNA cloning of p80-coilin. J Exp Med, v. 173, p. 1407-19, 1991.

5. ANDRADE, L. E. C. et al. Two major autoantigen-antibody systems of the mitotic spindle apparatus. Arthritis Rheum, v. 39, p. 1643-53, 1996.

6. ARBUCKLE, M. R. etal. Development of autoantibodies before the clinical onset of systemic lupus erythematosus. $N$ Engl J Med, v. 349, n. 16, p. 1526-33, 2003.

7. BARCELLOS, K.S. et al. Differential expression of Ro/SSA $60 \mathrm{kDa}$ and La/SSB, but not Ro/SSA 52 kDa, mRNA and protein in minor salivary glands from patients with primary Sjogren's syndrome. J Rheumatol, v. 34, n. 6 , p. 1283-92, 2007.

8. BONFA, E. et al. Association between lupus psychosis and anti-ribosomal $\mathrm{P}$ protein antibodies. N Engl J Med, v. 317, n. 5, p. 265-71, 1987.

9. BORG, A. A.; DAWES, P. T.; MATTEY, D. L. Autoantibodies to nuclear lamins and to intermediate filament proteins. J Rheumatol, v. 20, p. 1988-90, 1993.

10. CARBALLO, O. G. et al. Atlas Anti-Nucleocitoplasmaticos (HEp-2). Buenos Aires: Talleres Gráficos TBS, 2006.

11. CHOU, M. J.; LAI, M. Y.; LEE, S. L. Reactivity of antimitochondrial antibodies in primary biliary cirrhosis and systemic sclerosis. J From Med Ass, v. 91, n. 11, p. 1075-80, 1992.

12. DEANE, P. M. G. et al. The outcome of children referred to a pediatric rheumatology clinic with a positive antinuclear antibody test but without an autoimmune disease. Pediatrics, v. 95, n. 6, p. 892-5, 1995.

13. DELLAVANCE, A. et al. $3^{\circ}$ Consenso Brasileiro para pesquisa de autoanticorpos em células HEp-2 (FAN). Recomendações para padronização do ensaio de pesquisa de autoanticorpos em células HEp-2, controle de qualidade e associações clínicas. Rev Bras Reumatol, v. 49, n. 2, p. 89-109, 2009.

14. DELLAVANCE, A. et al. I Consenso Nacional para Padronização de Laudos de FAN HEp-2. J Bras Patol Med Lab, v. 38, n. 3, p. 207-16, 2002.

15. DELLAVANCE, A. et al. II Consenso Brasileiro de Fator Antinuclear em Células HEP-2 Definições para padronização da pesquisa de autoanticorpos contra constituintes do núcleo (FAN HEp-2), nucléolo, citoplasma e aparelho mitótico e suas associações clínicas. Rev Bras Reumatol, v. 43, n. 3, p. 129-40, 2003.

16. DELLAVANCE, A. et al. Pesquisa de autoanticorpos em células HEp-2. Editora UCG, Goiânia, 2008.

17. DELLAVANCE, A.; ANDRADE, L. E. C. Como interpretar e valorizar adequadamente o teste de anticorpos antinúcleo. J Bras Patol Med Lab, v. 43, n. 3, p. 15768, 2007.

18. EYSTATHIOY, T. et al. A phosphorylated cytoplasmic autoantigen, GW182, associates with a unique population of human mRNAs within novel cytoplasmic speckles. Mol Biol Cell, v. 13, p. 1338-51, 2002.

19. FORSLID, J. et al. The prevalence of antinuclear antibodies in healthy young persons and adults, comparing rat liver tissue sections with HEp-2 cells as antigen substrate. Clin Exp Rheumatol, v. 12, n. 2, p. 137-41, 1994.

20. FRANCOEUR, A. M. et al. Identification of Ki (Ku, p70/ p80) autoantigens and analysis of anti-Ki autoantibody reactivity. J Immunol, v. 136, n. 5, p. 1648-53, 1986.

21 FRITZLER, M. J. et al. Antinuclear, anticytoplasmic and anti-Sjögren's syndrome antigen A (SS-A/Ro) antibodies in female blood donors. Clin Immunol Immunopathol, v. 36 , p. $120-8,1985$

22. FRITZLER, M. J.; KINSELLA, T. D. The CREST syndrome: a distinct serologic entity with anticentromere antibodies. Am J Med, v. 69, n. 4, p. 520-6, 1980.

23. GÖRING, H. D. et al. Association of Scleroderma and Primary Biliary Cirrhosis - results of a systematic study on a dermatological clientele. Hautarzt, v. 49, p. 36166, 1998.

24. ISSHI, K.; HIROHATA, S. Differential roles of the antiribosomal $P$ antibody and antineuronal antibody in the pathogenesis of central nervous system involvement in systemic lupus erythematosus. Arthritis Rheum, v. 41, n. 10, p. 1819-27, 1998.

25. JARZABEK-CHORZELSKA, M. et al. Scl-70 antibody, a specific marker of systemic sclerosis. Br J Dermatol, v. 115, n. 4, p. 393-401, 1986.

26. KRAPF, A. et al. Human autoimmune diseases and autoantibodies. Bol Com Íbero-Americano Reumatol, v. 9, p. 55-8, 1999.

27. KRAPF, A. R. et al. Atlas of immunofluorescent autoantibodies. Munich: Urban \& Schwarzenberg, 1996.

28. LEIBOVITCH, L. et al. Antiactin antibodies in sera from patients with autoimmune liver diseases and patients with carcinomas by ELISA. Immunol Lett, v. 48, n. 2, p. 129-32, 1995.

29. LESER, P. G. et al. Distinctive features of antinuclear antibodies observed in health and in subjects with autoimmune rheumatic disease. In: CONRAD, K. et al. From animal models to human genetics: research on the induction and pathogenicity of autoantibodies. Dresden: Pabst, 2004. p. 493-510.

30. LOHSE, A. W. et al. Characterization of the overlap syndrome of Primary Biliary Cirrhosis (PBC) and 
Autoimmune Hepatitis: evidence for it being a hepatitic form of PBC in genetically susceptible individuals. Hepatology, v. 29, n. 4, p. 1078-84, 1999.

31. MASSABKI, P. S. et al. Clinical implications of autoantibodies in HIV infection. Aids, v. 11, n. 15, p. 1845-50, 1997.

32. NOTMAN, D. D.; KURATA, N.; TAN, E.M. Profiles of antinuclear antibodies in systemic rheumatic diseases. Ann Intern Med, v. 83, n. 4, p. 464-9, 1975.

33. OCHS, R. L. et al. Autoantibodies to DFS $70 \mathrm{kd} /$ transcription coactivator $\mathrm{p} 75$ in atopic dermatitis and other conditions. J Allergy Clin Immunol, v. 105, n. 6, p. 1211-20, 2000.

34. REIMER, G. et al. Human autoantibodies: probes for nucleolus structure and function. Virchows Arch B Cell Pathol Incl Mol Pathol, v. 54, p. 131-43, 1987.

35. RUBIN, R. L. Autoimmune reactions induced by procainamide and hydralazine. In: KAMMULLER, M.; BLOKSMA, M.; SIEMEN, W. Autoimmunity and
Toxicology: Immune Dysregulation Induced by Drugs and Chemicals. Amsterdam: Elsevier, 1988.

36. TAKASAKI, Y.; DENG, J. S.; TAN, E. M. A nuclear antigen associated with cell proliferation and blast transformation. J Exp Med, v. 154, p. 1899-909, 1981.

37. TAN, E. M. et al. Range of antinuclear antibodies in "healthy" individuals. Arthritis Rheum, v. 40, n. 9, p. 1601-11, 1997.

38. TARGOFF, I. N. Autoantibodies in polymyositis. Rheum Dis Clin North Am, v. 18, p. 455-82, 1992.

39. von MÜHLEN, C. A.; NAKAMURA, R. M. Clinical and laboratory evaluation of systemic rheumatic diseases. In: McPHERSON, PINCUS. Clinical diagnosis and management by laboratory methods. Philadelphia: W.B. Saunders, 2006.

40. YANG, Y. et al. Clinical features of several connective tissue diseases with anti-Golgi antibody. Ann Rheum Dis, v. 60 , p. $986-87,2001$

\begin{tabular}{l|l} 
Endereço para correspondência \\
\hline Laboratório de Apoio Didático \\
Departamento de Biomedicina da Universidade Católica \\
de Goiás (UCG) \\
Avenida Universitária, 1.069 - Setor Universitário \\
CEP: 74605-010 - Coiânia-Co \\
Tel.: (62) 3946-1393 \\
e-mail: lad@ucg.br
\end{tabular}

9. Professor de Reumatologia da Faculdade de Medicina da Pontifícia Universidade do Rio Grande do Sul (FMPUCRS); doutor em Medicina pela Faculdade de Medicina da Rheinisch-Westfalische Technische Hochschule/Aachen, Alemanha; pós-doutorado no The Scripps Research Institute, La Jolla, EUA; diretor técnico do Metanalysis Centro de Diagnósticos Médicos, Porto Alegre.

10. Médico e biomédico; especialista em Patologia Clínica; especialista em Saúde Pública; mestrando em Biologia de Agentes Infecciosos e Parasitários pela Universidade Federal do Pará (UFPA); supervisortécnico do Laboratório Amaral Costa; professor de Patologia Clínica do Centro de Educação Técnica do Estado do Pará (CESEP).

11. Assessor científico da NewLife Comércio de Produtos Laboratoriais.

12. Laboratórios de Investigação Médica do Hospital das Clínicas da Faculdade de Medicina da Universidade de São Paulo (FMUSP).

13. Mestra em Medicina Tropical pela Universidade Federal de Goiás; Professora assistente da disciplina de Imunologia da UCG.

14. Médico patologista clínico e reumatologista; doutor em Patologia pela FMUSP; médico da seção de Imunologia da Divisão de Laboratório Central (LIM 03) do Hospital das Clínicas da FMUSP; gerente médico do Departamento de Patologia Clínica (Diretoria de Medicina Diagnóstica e Preventiva) do Hospital Israelita Albert Einstein.

15. Médica patologista clínica de Imunologia do Instituto Hermes Pardini.

16. Biologia celular e molecular; suporte técnico-científico da Biometrix Diagnóstica.

17. Professora titular de Reumatologia da FMUSP.

18. Médico patologista clínico do Laboratório Atalaia.

19. Exame medicina laboratorial do Distrito Federal.

20. Médico patologista clínico e virologista; pós-graduação em Biologia Parasitária pela Fundação Oswaldo Cruz (FIOCRUZ); consultor científico do setor de Imunoensaios do Sérgio Franco Medicina Diagnóstica.

21. Médica reumatologista e coordenadora do laboratório de Imuno-Reumatologia do Hospital das Clínicas da Faculdade de Medicina da UCC (FMUCC).

22. Mestra em Ciências Médicas pela Universidade Federal de Santa Catarina (UFSC); professora da Universidade do Sul de Santa Catarina (UNISUL); professora da Universidade do Vale do Itajaí (UNIVALI); patologista clínica do Laboratório Médico Santa Luzia.

23. Mestra em Biomedical Science pela San Francisco State University, Califórnia; bioquímica dos Laboratórios Saúde e Hospital e Maternidade e Jardim América.

24. Assessora científica da Hemagen Diagnósticos.

25. Pós-Doutorado pela University of Calgary; médico reumatologista da Universidade Federal da Bahia (UFBA); professor adjunto da Fundação Bahiana para Desenvolvimento das Ciências; chefe do serviço de reumatologia do Hospital Santa Izabel.

26. Médica patologista clínica; mestra pediatria pela USP; professora da Universidade Federal de Mato Crosso (UFMT).

27. Doutor em reumatologia pela USP; professor titular de reumatologia da FMUCC.

28. Mestra em Medicina Tropical pela UCG; biomédica do Padrão Laboratório Clínico.

29. Assessor Científico da Alka.

30. Doutor em Ciências Biológicas (Biofísica) pela Universidade Federal do Rio de Janeiro (UFRI); estatutário da Universidade do Estado do Rio de janeiro (UER)); professor adjunto de reumatologia da UER); coordenador do Centro de Autoimunidades do Hospital Pró-cardíaco; consultor científico do Diagnósticos da América SA.

31. Doutora em Imunologia pelo Instituto de Ciências Biomédicas (ICB) da USP; formada pela FMUSP; especialização em Reumatologia pela FMUSP; médica do setor de Imunologia do Laboratório Diagnósticos da América SA.

32. Médica patologista clínica; doutora em Ciências pela FIOCRUZ; professora adjunta da Faculdade de Medicina da Universidade Federal de Minas Cerais (FMUFMG); coordenadora do setor de SoroImunologia do Serviço de Medicina Laboratorial do Hospital das Clínicas da UFMC.

33. Médico reumatologista; coordenador do Laboratório de Reumatologia do Hospital Universitário de Braślia e doutor em Reumatologia pela UNIFESP.

34. Mestra em Patologia Molecular/Imunologia pela Universidade de Brasilia (UNB); professora da União Educacional do Planalto Central e do Centro Universitário Euro-Americano (UNIEURO); assessora científica da Imunotech Sistemas Diagnósticos Importação e Exportação. 